Revista Mídia e Cotidiano Artigo Seção Livre

Volume 13, Número 1, abril de 2019

Submetido em: 24/10/2018

Aprovado em: 08/01/2019

\title{
THE PRACTICE OF ONLINE RE-INFORMATION ${ }^{1}$
}

\section{A PRÁTICA DA RE-INFORMAÇÃO ONLINE}

\author{
Leda MANSOUR ${ }^{2}$
}

\begin{abstract}
The purpose of this article is to study the practice of online re-information. The case studied is the sphere of re-information on the French web, namely hundreds of sites and blogs in connection with the ideas of the French far right practicing re-information, where new information is proposed on political, religious, social or cultural news. While the use of the prefix re- in "re-inform" indicates the idea of renewal and a critical revision, it is used by re-information sites to mark rather a counter-information, a denial or a rejection of any other information. After having defined the practice of re-information, the hypotheses and the methodology, our study focuses on the discursive and communicational orientations in the re-information sphere before bringing elements of interpretation by relying on the question of the false information and on studies on the sociology of beliefs.
\end{abstract}

Keywords: re-information, réinfopshère, french far right, fake news, online practices, sociology of beliefs

\section{Resumo}

O objetivo deste artigo é estudar a prática da re-informação online. O estudo de caso aqui apresentado contempla a esfera de re-informação da web francesa, especificamente, centenas de sites e blogs em conexão com ideias da ultra direita que pratica re-informação. Através dessa prática, novas informaçãos acerca de notícias políticas, religiosas, sociais e culturais são propostas. Ao mesmo tempo em que o uso do prefixo "re" em re-informar carrega uma ideia de renovação e revisão crítica, ele é utilizado por sites de re-informação para demarcar uma contra-informação, uma negação ou rejeição de uma outra informação. Após definir o que seria a prática de re-informação, a hipótese e metodologia, nossa estudo aborda as orientações discursivas e comunicacionais da esfera de reinformação antes de incorporar elementos de interpretação e questões relativas à falsa informação, assim também como estudos da sociologia de crenças.

Palavras-chave: re-informação; re-infosfera; ultra direita frances; fake news; práticas online; sociologia das crenças

\footnotetext{
1 This article was translated from French into English by Irina Kalderon Libal. The title in French is $L a$ Pratique de la Re-informacion Online

2 Postdoc - Chair "Dialogue of Cultures" at Paris 1 Panthéon-Sorbonne |Email: ledamansour@ hotmail.com.
} 


\section{Introduction}

The purpose of this article is to study the practice of online re-information. The case studied is the sphere of re-information on the French web, namely hundreds of sites and blogs in connection with the ideas of the French far right practicing re-information., where new information is proposed on political, religious, social or cultural news. While the use of the prefix re- in "re-inform" indicates the idea of renewal and a critical revision, it is used by re-information sites to mark rather a counter-information, a denial or a rejection of any other information. After having defined the practice of re-information, the hypotheses and the methodology, our study focuses on the discursive and communicational orientations in the re-information sphere before bringing elements of interpretation by relying on the question of the false information and on studies on the sociology of beliefs.

\section{The re-information}

According to a survey by Schmelck, the term re-information was claimed by "Henry de Lesquen, a right-wing politician and leader of Radio Courtoisie, then it was taken by Jean-Yves Le Gallou for his Bulletin of re-information on the same radio" (SCHMELCK, 2017, p. 207). In the journal Medium, the journalist published interviews with consumers and producers of re-information, such as Louis Lorphelin, who defines this practice: "It is assumed that the traditional media lie to us, or hide part of the reality" (ibid.). The studies on re-information associate this term with the ideas of the extreme right, hence, in their study on a Swiss re-information site and its connections, Jammet and Guidi specify: "In any event, the" re-information" today is mostly associated with the extreme right and the circulation of conspiracy theories "(2017, p. 255). Associated with the ideology of the extreme right, however, these re-information sites do not seem homogeneous; a study on Catholic traditionalist sites on the web, states that the reinformation sphere is heterogeneous, depending on the claims of different groups (BLANC, 2015). However, the common denominator is the objective of "rereading the current events in the light of the Catholic tradition [...], placing the actors who animate it 


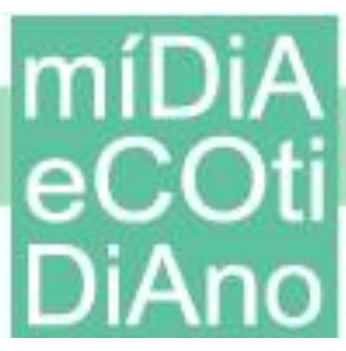

more in an interpretative logic of the current (political, religious, cultural and moral) events and therefore representing more an opinion, than real information" (ibid.).

Thus, in this blogosphere re-informing seems to refer to disavowing traditional media, to propagate conspiracy theories, and not to offer a new informational offer. These are indeed the results of our observation on hundreds of sites and blogs of the French reinformation sphere: their focus is rather on counter-informing, denying or even playing on the fictional, the myth and the beliefs. The studies mentioned sometimes focus on the very content of the re-informing sites (in connection with the ideology of the far right) or on describing some communication strategies, but we do not dwell on the very meaning that sites give to their act of re-information. What our contribution wants to develop is to demonstrate the ambiguous and indecisive use of the prefix re-that would suggest a renewal of information. For this purpose, we sought to describe the different meanings of the verb re-inform used in the studied sites. These descriptions of the term "to re-inform" brought to light two discursive orientations: first, an opposition between lie and truth, then a play on beliefs, myths and fiction. In order to provide interpretive elements, we question these two orientations in the light of the current debate on false information online, with studies in Information and Communication Science on the one hand, and in sociology of beliefs on the other hand.

\section{Assumptions, corpus and methodology}

Our study is based on data provided by Linkfluence ${ }^{3}$, as part of an ANR project "Algopol: Algorithmic Policy"4 . Linkfluence has gathered around a hundred sites, taking into account citation links between these sites on one side and sites on the far right on another. This collection of sites is made on the basis of the principle of transitivity in sociology of social networks "the friends of my friends are my friends" (HEIDER, 1946, quoted by MERCKLÉ, 2004, p. 63-64). Linkfluence's study of the outgoing and incoming quotation links of the re-information sphere shows that the re-information sites are

\footnotetext{
${ }^{3}$ Linkfluence is a European social media start-up offering studies for social media analysis and web mapping

${ }^{4}$ ANR coordinated and directed by Camille Roth (2012-2015)
} 


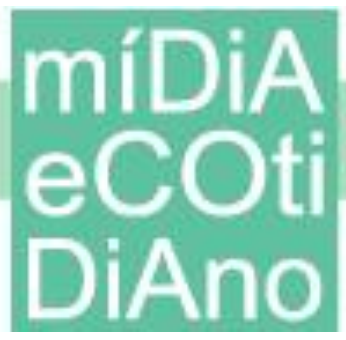

essentially pointing to themselves and to the political blogosphere of the far right. However, their relationship of affinity or "friendship" does not, in our opinion, constitute a reason for considering them a body of study. It is our observation of the sites that will make a selection in these sites, to remove some and add others that were not part of the Linkfluence data. This observation of the re-information sphere extends over the period between 2014 and 2015 and leads to the following hypothesis: the majority of the sites are defined, implicitly or explicitly, as re-informers whose objective is to renew and redo the information, hence their use of the verb re-inform. However, we have identified a discourse of counter-information, denial and clean-shave effect on traditional media, politicians and academics or intellectual figures. This counter-information is far from presenting a work of renewal and recommencement as suggested by the prefix re- in reinform. To demonstrate this paradox, we adopted a lexicological approach, namely the study of associative fields, as theorized by Picoche (1992). The associative field is part of the semantic lexical fields, it is defined as "a set of words frequently associated in contexts dealing with the same subject" (ibid, p. 49). In our case, the subject is the wordpole "re-inform" or "re-information", in a precise discursive context that is that of supporters of the French far right. Our analysis consists in identifying the words associated, closely and remotely, with re-information, and as Picoche says "with consideration of the most mundane associations" (ibid, p. 66). These associations are used by the sites themselves, so we have been careful to locate them in:

- designation and naming methods: site names and site categories (headings).

- names of hyperlinks: links and links to other sites and other sources.

- in the "who are we", "about" and "welcome" sections, the "charters" of the sites but also in the published posts.

We made an online observation by taking screenshots of headings and any piece of corpus, which we do not publish for copyright issues; we still mention the names of sites. Our study will expose two lexical orientations: the opposition lie / truth, and the game on beliefs, myths and fiction. The opposition between lie and truth allows us to ask the question of false information. Secondly, practices based on beliefs and myths lead to the provision of interpretative approaches based on the sociology of beliefs, in order to 


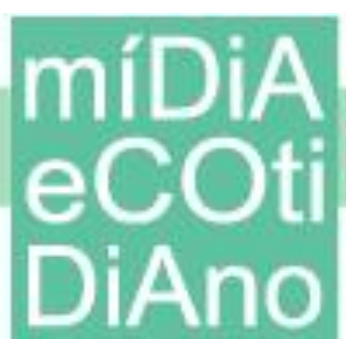

help us think about our object through the question of adherence to beliefs. To this end, we use Bronner's studies and what he calls "precautiousness" in The Disturbing Precautionary Principle (BRONNER AND GÉHIN, 1995), or his study of contemporary Beliefs and Imaginaries (BRONNER, 2013b). Above all, we use his essay The Democracy of the credulous (2013a), which proposes a reflection on the sometimes ideological expectations of citizens, pushing them to believe false information, conspiracy theories, hoaxes and rumors. These beliefs are, according to the author, accentuated by the cognitive market, very competitive in the context of the web. Before describing the lexical orientations of the re-informing sites, we stop on the effects of meaning of the prefix re-, and this is in order to better account for its misuse.

\section{The prefix re-}

In his thesis, Maschrin reports on the literature on the prefix re-, specifying the sometimes contradictory hypotheses on the delimitation of the meaning of the prefix (MASCHRIN, 2007). Derivative morphology and morpho-semantic studies raise the question of the meaning of the re-prefix in a different way: some approaches take into account the prefix and the basic word in the construction of the effects of the senses (associative approach) and others separate the prefix of its base (dissociative approach) (JALENQUES, 2002). What interests us in this literature is which semantic instruction carries the prefix in a case like the verb re-inform in the context of re-informing sites. It seems that most studies give the prefix re- the idea of iteration or repetition as in Paul retook the cake (ibid, 2002). However, this idea does not cover all the interpretations: there are effects of meaning that go beyond the idea of iteration, to suggest an effect of novelty, even of interruption. Jalenques gives the following example Paul reclassified his stamps to account for "a relationship of change":

Instead of the previous standings, there is a new ranking. RE means that the event in time of the second classification modifies the situation defined by the event in the time of the first classification. More generally, we argue that the prefix RE means that the update of the process associated with the verbal base (P2) modifies the situation resulting from the updating of a first trial (PI). (JALENQUES, 2002). 


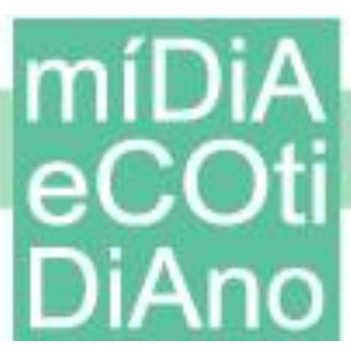

This modifying effect created by the prefix $r e$ - is emphasized differently in Maschrin's work, which, beyond interactivity, speaks of an idea of a "backtracking" as in After entering, I close the door again meticulously behind me. According to Maschrin, there is an effect of cancellation meaning: the first result is canceled to reach what he calls, following the studies of Amiot (2002), "a return to a previous state" (MASCHRIN, 2007).

In this logic, we can think that in re-informing, the speakers designate either the idea of a revision of a given information (repetition effect), or of an information redone from a first that would be "canceled" and "modified". However, what happens on the sites of the re-information sphere? Would we be dealing with revised information? Or renewed? Would this information be redone for the sake of precision and constructive and renewing criticism? Our hypothesis wants to demonstrate an ambiguous use of the prefix re-, so we start by studying the first lexical orientation, that of the division operated by these sites: to divide the world in two, on the one hand the world of the lie and on the other hand that of truth.

\section{Lie and truth}

On the re-information sites, the same information (or post) can be put under names of different categories (or headings), which makes it possible to bring these category denominations closer together semantically. Indeed, the blog Arnaud de Brienne stores the same posts under "Re-information, Disinformation, Resistances, Single Thought, Harmful" or even "Duty of Memory." Admittedly, there is no direct link between "reinformation" and "single thought" or "resistance", but in the logic of the editors of the site, a link is assumed. A search on the site altermedia.info around the verb re-inform or the term re-information gives access to the same post in four different categories, including "semantic war", "manipulation" and "disinformation". This organization of categories and the storage of posts suggest that the act of reinventing is also an act of misinformation, in addition to a linguistic activity of semantic precision, of course, but which refers to the warlike character of the negotiation on meaning. This goes beyond the verb to re-inform and opens up to other issues such as misinformation, where, with 
the prefix $d e(s)$ - we move away from the idea of a renewal of information; instead, we give false information to influence the debates. Moreover, the meaning of re-inform widens by referring to the expression of a positioning: as it is "semantic", this does not prevent it from being considered as "a war" thus making it possible to bring together ideas of "feedback on information", "transmission of false information" and possibly "conflictual character of the way information is produced". These category names seem to take on a more extreme aspect on the euro-jihad website, where the same post is placed under the headings "propaganda, collaboration sphere, censorship".

To re-inform seems to indicate for these sites several other senses. We can gather these words in a possible associative field, which would have as common denominator or theme-pole "the informational lie", even "the intellectual terrorism", where one would supposedly bathing in a world of lie; these, on the site the Organ, are associated with the term manipulations, as in the text in a post:

The Manif for all highlights the lies of Minister Benoît Hamon Press release of La Manif for all:

The students (boys!) of Nantes are of course not "obliged" (still happy!), but indeed "invited" to wear a skirt next Friday. Stop the lies and manipulations!

From the moment when re-informing seems to have a meaning in relation to the question of the false, we can then work on the lexicon relating to the truth and the lie. It exists very often in the menus of the blogs. We read on the website the Strasbourg right the category names "The Left lies" "The Right betrays".

This negative part of the information world has its positive side, which consists of telling the truth, which ultimately defines the very act of re-information. The opposite cases to the denomination described above do exist. We have the category names like "Truth on ..." "All About ...". Or the example on the Republican Resistance website: "All about Halal" "Truths about Halal and some child deaths". These sites therefore offer truths that are supposedly being ignored by journalists. The meaning of re-information does not stop with the indication of lies, misinformation and propaganda, but it depends on the ability to bring the truth, the latter being the very name of certain sites, such as The 4 truths and Truth Value Democracy or Boulevard Voltaire, which, without mentioning the 


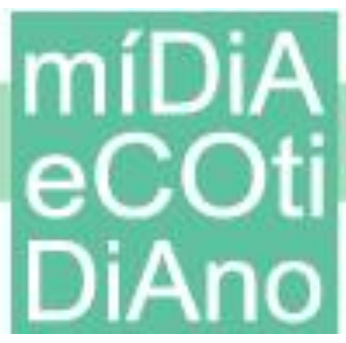

term of truth, creates a truth effect by opting for the name of the philosopher. The truth would therefore mark the end of the lies, as suggested by the blog Dreuz.info in a title of one of his posts, emphasizing "to finish it": "To put an end to the crazy idea that Christ was ... "(DEUZ.INFO, ONLINE CORPUS, 2014-2015). Elsewhere on the blog Gerard Bazon, we read the title: "Ending with these French media of shame" (GÉRARD BAZON BLOG, ONLINE CORPUS, 2014-2015).

Emphasis is placed on the need to put an end to "shame", that is to say as the text of the post in the last example mentions the "wills not to inform" and "to affirm counter truths", but also, in the first example, put an end to the absurd and ridiculous ideas. We are still in the lexicon that claims the necessity of the truth. Now this indication is here expressed with an effect of cessation and rupture "to finish with", as to settle an account. In this orientation we can hear the certainty that slices, because it recognizes the share of lies and truth. What is the case in the text of a post presented as pertaining to information rather true, because "to believe", even "to have to be believed":

"Here in 10 points what believe or should believe..." (DREUZ.INFO, ONLINE CORPUS, 2015). "Here", a presentative whose interest in its morphological construction ("see" and "ci") is to account for the presence of the verb "to see", thus an effect of vision or to make see, seems to announce "10 points "to believe and to ought to believe, though the verb duty is used in a conditional mode, probably to alleviate the obligatory character of belief. However, the conditional hardly removes the tone of certainty, which, besides the use of the verb "must" and the presentative "here", is manifested by the form of the text presented by means of a numbered list, as if it was about reading a directory. This tone of certainty is rather confirmed, if not taken for granted, on the site extremcentre.com, which will build two categories explicitly dividing the world into two parts: on one side, the part of "knowledge" and, of another side, that of "ignorance":

"It is in the world that you will learn that"

"It's not in the world that you will learn that" (EXTREMECENTRE, ONLINE CORPUS, 2014-2015)

This example is reminiscent of a communication strategy in the press headings that evaluate the value of this or that event, or of such or such a comment as the case in 


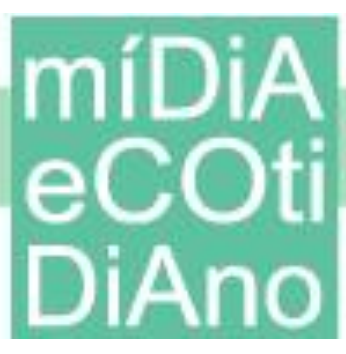

Magazine literary, with the headings of "rising" and " falling ". On another site of the reinformation sphere, we have the headings "fit" and "down" (MINUTE-HEBDO.FR, ONLINE CORPUS, 2014-2015).

In this type of rubric, the sites of the re-information sphere insist on a lie / truth dichotomy "you will learn" "you will not learn". Nevertheless, this is not unique to these sites and exists elsewhere in so-called traditional media sites. For example, there is a detox section on the website of the newspaper Libération. This section wants to deny information and comments produced by politicians and others. Should we then leave our corpus to generalize these uses that offer other information more accurate, truer? The interest to leave the re-information sphere does not lie in the comparison with other media and spheres in the public space: the comparison can lead to a generalization that would confuse uses, because it would take them out of their political contexts and their ideological anchors. Thus, the output of the re-information sphere is necessary, not to hunt elsewhere the same act of re-information, but to better understand it by situating it in a dominant phenomenon, that of false information online (The fake news).

\section{The question of false information}

The circulation of false information seems to preoccupy researchers, journalists, educators, politicians and citizens. Beyond an "era of truth" as we read in newspaper headlines, we are witnessing a phenomenon that is gaining more and more importance precisely in online social networks. Thus, in the press, like Le Monde, Libération or other newspapers, we can read articles dealing with false information circulating in the social network Facebook during the American presidential campaign, to the point that the network could be accused of facilitating the circulation of fake content. So, we read headlines like "Success of false information in the last months of the American campaign ${ }^{5 "}$. This has lead Google's search engine, for example, to creating a system of fact-checking 6 , or the newspaper Le Monde to "fight against false information" by

\footnotetext{
${ }^{5}$ http://www.lemonde.fr/pixels/article/2016/11/17/l-essor-des-fausses-informations-dans-les-derniersmois-de-la-campagne-americaine_5032435_4408996.html

${ }^{6}$ https://www.theguardian.com/technology/2016/oct/13/google-news-fact-check-trump-clinton-uselection
} 


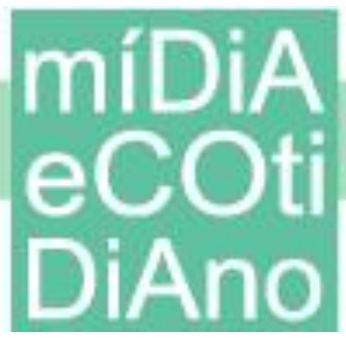

collaborating with twenty media "to reduce the scope of rumors circulating on the Internet"7 . Sites like Hoaxbuster aim to check the hoaxes of the web, often in connection with right-wing fan sites including re-information sites. We can find on YouTube videos called "little course information retrieval on the internet" that offer to teach users to check the information or what they call to practice "intellectual self-defense" ${ }^{8}$. This discourse on false information can be found elsewhere in the titles of popular science magazines such as Science and the Future, where we can read titles such as "truth on..." that enlighten readers on a scientific subject: environment, pollution and others. This phenomenon also goes beyond the media and social networks to preoccupy the university community, where a recent issue of the 30th issue of Le Temps des médias is devoted to this issue with a historical approach, where the extent of this old phenomenon is expressed since the "practice of fictionalization of information in the press, spread since the XVII and XVIII centuries" to "the new attractiveness of conspiracy theories $9 "$. As Badouard says: "The fake news meets a craze", which is linked by the author to "the ideological confinement of one side and the industrialization of misinformation on the other hand" (BADOUARD, 2017, p. 42). Moreover, the author believes that the success of fake news expresses "a virulent defiance towards the political and intellectual elites. Their goal is to question the legitimacy of the "word of authority "that is journalists, elected representatives and academics"(ibid, p. 44). However, this mistrust of traditional media is the subject of the work of some activist media as developed by Cardon and Granjon in their book Médiactivisme about alternative media battling the informational hegemony of news feeders (CARDON and GRANJON, 2010). The authors mention on the part of these media a form of calling into question the "passive relationship to information". Admittedly, the media referred to in their study have nothing to do with the re-information sphere, in the sense of political and ideological content. But the basic idea in the activist media is, according to the authors, to practice counter-information by alternative groups against the power of the big decision-makers in traditional media (ibid.). The authors talk

\footnotetext{
${ }^{7}$ http://www.lemonde.fr/les-decodeurs/article/2017/02/28/lutte-contre-les-fausses-informations-lemonde-partenaire-du-projet-crosscheck_5086731_4355770.html

${ }^{8} \mathrm{https}: / /$ www.youtube.com/watch?v=2XPtzAQxMPw

${ }^{9}$ Appel à contribution: http://www.histoiredesmedias.com/Appel-a-contribution-La-Fausse.html
} 
about the idea of "Do not hate the media ... Became the media" that blossoms in the age of the internet. This is the case of the re-information sites, which specify for example on minurn.blog4ever:

Three years ago, faced with the terrible threats hovering over France, we created" Minurne ", a free space for information and debates aimed at combating misinformation and intoxication practiced by the media on the orders of the public well-thinking and the politically correct. (ONLINE CORPUS, 2014-2015)

Cardon and Granjon explain that alternative media are made to fight the misinformation of citizens, which, as we have seen, is the goal of re-information sites. An objection can be made concerning the ideological anchoring of sites: an ecologist site that fights against misinformation about this or that food could not be compared to a site in the re-information sphere, which builds this information related to ideology from the extreme right. For example, the re-information sphere deals with a variety of topics that are quite focused on "Muslims" and "Jews", not to mention the treatment of political news, often selected according to taste. On the site contre-info.com, which gives itself the task of making alternative information, the strategy of re-information is to fight against an advertising campaign of the Caf about frauds. The re-informing website implicates what it calls the "white French type profile" advertising photo and will therefore post a list of names of "real" fraudsters (CONRTE-INFO.COM, ONLINE CORPUS, 20142015). In this published list, we discover that the typical profile, according to contreinfo.com, would be people whose names are Arabic-sounding. Here is one of the many examples of re-information, not to mention the dismantling of the thought of Sigmund Freud defined as Jewish on the site of wrongdoer who, in a long article, denounces "the mental manipulation of Freudian psychoanalytic theory."

If the content differs between re-informing sites, environmental sites, alternative and militant information sites, disinformation sites of any political party and all sides, it is not illegitimate to specify that there is the same state of mind, that of replacement. Replacing one information with another, one media with another, or one truth with another, seems to animate both the question of false information, but also the creation of alternative groups of counter-information and counter-power. It goes without saying that 
the motivations are not the same between blogs and media. Criticism of the media by socalled critical pessimism theories like those of Chomsky which "overestimate the power of the big media to frighten readers and push them to action" (JENKINS, 2006, translated in GLEVAREC, MACÉ, MAIGRET, 2008). Jenkins adds about this critical pessimism: "it is about victimization and vulnerability, seduction and manipulation," propaganda machines "and" weapons of mass concealment "(ibid, p. 339). The reinvigorating partisans of the French far right may have no connection with the theorists of critical pessimism or, we draw attention to the use of the same lexicon and the traditional antimedia posture thus expressed and shared by groups belonging to ideological anchors sometimes opposed. However, the re-information sphere does not stop at this posture, nor at the division true / false, but it draws on a lexicon going beyond the question of the truth to reach that of the fiction, the myth and the game on the beliefs.

\section{Myth, fiction and beliefs}

Many of the re-informing sites refer to titles of books "to read" bringing the truth on a subject, but also to documents on various subjects. These documents are designated and make use of lexical terms that contrast reality with myth. The myth brings to light the fictitious part of the information as on the site résiliencetv.fr, where one finds the category designated by "Myths and realities of the conflicts on the Middle East" (RESILIENCETV.FR, ONLINE CORPUS, 2014 -2015).

Elsewhere on the site scriptoblog.com, the speech mentions "an imaginary France" and invites to "compare this fiction to your reality" talking about TV or "teloche", as indicated in the text of a post:

Imagine, you're in front of the television. You watch a French series. Compare this fiction to your reality. You live in a society where politician and scammer have practically become synonymous. The teloche does not speak of the world where you live. She does not speak of your France. She speaks of an imaginary France. (SCRITOBLOG.COM, ONLINE CORPUS, 2014-2015)

We have elsewhere on the site unvoyageauliban.bafweb.com an association made between "newspapers" and "novelists", even the image of a film in slow motion concerning the information in the newspapers: 
All we do not know and that's huge!

Newspapers embroider these stories that novelists would have liked to invent.

Other non-news fill the newspapers.

Like a movie in slow motion ...

All these absences of news are also a way to nourish the impatience of an era that prefers to speak of the hypothetical rather than confront the real ${ }^{10}$

On these sites, one also observe the strategy of re-information, which consists in first to clarify that this information is a hoax or false, but that then one can always believe it. This is the case in the following example on the site la voixdupeuple in her post titled "Letter to a social worker at TF1":

"Thanks to Someone for pointing out that this article was a hoax that has been circulating for several years. That said, everyone is free to agree or disagree with the arguments put forward.

This precision joins our previous examples around the invitation to "believe" and "to believe". Here we have an incentive, despite the false nature of information, to "agree". We might think that the false nature of information is of little importance for these sites, from the moment this information makes it possible to report an argument or to confirm an idea compatible with the beliefs and convictions of these speakers.

This omission of the false seems contradictory with an insistence on veracity in the form of a dichotomy of ignorance and knowledge, as on the blog Gerard Bazon, which questions the knowledge of an academic and scholarly personality (ABDELWAHHAB MEDDEB, who was a specialist among others of Islam). We read indeed on this blog:

Is Mr. Meddeb ignorant of these Quranic verses ... Mr. Meddeb knows it better than anyone else. Is he amnesiac enough to forget that [...] How can he ignore the deeds of the Messenger of Allah? He must know at least that...

And further in the same post:

Mr. Meddeb, knows that violence is sacred in Islam, while he stops smoking the French who have a vague knowledge of the ideology of Muhammad. He also refuses to acknowledge that.

\footnotetext{
${ }^{10}$ http://unvoyageauliban.bafweb.com/index.php?2011/05/18/810-tout-ce-que-nous-ne-savons-pas-et-quiest-immense
} 
These uses of the lexicon of not knowing about Islamologist and thinker Maddeb seem to be contradictory with the very work of this scholar who wrote a book critical of the Islamic religion entitled The Sickness of Islam ${ }^{11}$.

Along with the use of lexical terms referring to amnesia, silence and ignorance, the blog Gérard Bazon publishes videos on Islam by commenting on them in this way: "Watching this video, listening to this specialist in Islam, you will not be able to say that you did not know! You will not be able to say as for the Nazis that you did not know "(GERARD BAZON BLOG, ONLINE CORPUS, 2014-2015)

Here, the writer goes through the negative form to influence his reader who "now knows". In these examples, the emphasis is on knowledge, but especially on the need to believe: if an information is false, this does not prevent us from believing it. Moreover, a specialist in Islam is not a guarantee of truth according to these blogs; the questions about his amnesia invite him to reject his comments. We are not only in denial, but also in a state of rejection of the speeches and that of their selection according to convictions. This allows us to question the validity of the act of verification of information on the reinformation sphere: is it the question of veracity which is there the heart of their concern, or it is the beliefs, that this information makes it possible to trigger, which would interest some sites?

The last example "you cannot say you did not know" points to what Bronner, in his sociological studies, calls "the effect of unveiling", which "a bit like when you finally understand the solution to a logical or mathematical enigma, provides a great cognitive satisfaction, inspiring a dangerous feeling of certainty "(BRONNER, 2013a, 99). However, the question is not whether the re-information sphere provides an unveiling effect, and therefore a sense of certainty to its readers, but to try to understand why a reader, like a re-informator, adheres to attitude of over-suspicion of information. Here we come out of the re-information sphere to also include the question of false information, practices of misinformation and conspiracy theories, or even of any discourse inciting what Bronner and Géhin call "precautionism", which is an unconditional use, with an

${ }^{11}$ MEDDEB, AbDelwahHab (2005), La maLAdie DE L'ISLAm, PARIs, SeUil. 
ideological foundation, the precautionary principle (BRONNER AND GÉHIN, 1995). It seems that the posture of doubt and suspicion has become a privileged attitude, which Bronner also considers a source of concern:

And one that may be concerned that contemporary thought sees in generalized doubt and suspicion a mark of intelligence rather than a weakness of discernment. [...] This suspicion has spread beyond the lands of radicalism which, until recently, were the only spaces where it was heard. (2013a, p.17-19)

Bronner points to this posture, which consists in thinking that "everything can not be false ${ }^{12 "}$ (ibid., 92), such as the example of the rumor of the radioactive beaches in France, or beliefs about an alleged false death of Michael Jackson. The sociologist does not start from this false information and rumors, but from the adhesion of everyone: even journalists and specialists, or even politicians who can decide their policies on the basis of "fears" of citizens and an excess of precaution and not on the basis of scientifically validated knowledge ${ }^{13}$. It is precisely science, critical thinking and rationality that are indicted by this form of "credulity" or what Bronner calls "credulous expectations ${ }^{14 " . ~ I t ~}$ is a question of understanding "this obscure part of our rationality", which leads us to believe in erroneous information or as on the re-information sphere to believe in what is given for "authentic", on a mode of certainty that contrasts and incites to "have to believe".

Admittedly, the practice of reintroduction as well as its reception are not the only facts of an adherence to the false and the fictitious, but the sociology of beliefs invites to a work of readjustment; readjustment of positions and attitudes towards radical information and ideas, whether it be the re-information producer or the user-reader. The

\footnotetext{
12 See his explanations in the first chapter entitled "When more is less: massification of information and mental greed" about the argumentative millefeuilles or the "Fort effect" (in the name of Charles Fort) which consists in considering that "Everything can not be wrong"

13 "The temptation to please public opinion rather than serve the public interest is then great" (ibid: 265)

14 The figure of the scientist dominates some American television series as in the series "AO" or "Stranger things". The scientist is a sadistic being imprisoning "sample" subjects, such as laboratory mice, and exerts on them all types of tests marked by violence. These stereotypes about scientists are also circulating in the press during rumors or disinformation campaigns by public health advocates, campaigns that may themselves prove to be false (see also Bronner 2013b chapter 2).
} 


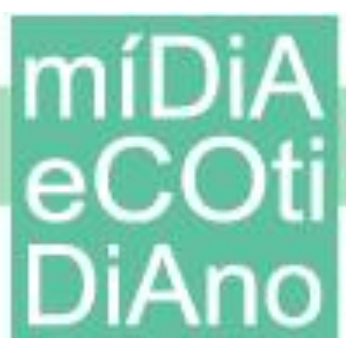

heart of this readjustment and Bronner's work is the question of trust, or, in our view, the possibility of its renewal.

\section{Conclusion}

"I demean," "I tell the truth," "I counter-inform," "I charge the manipulators and liars," "I unveil," "I reject," seem to be the different meanings of reinventing in the reinformation sphere. In this context of extreme lexicon, the reader first of all has his rationality, his discernment and his thought to adhere or not to the information presented as renewed. But, it is also in front of ways of saying, of ways of stating the content, which present to him the media and political horizon, even scientific, as pertaining to "lies", "manipulations" and "semantic war". We also spot the expression "Media tyranny" in a heading on the site abimopector.over-blog.com and in a quasi medical register we read on the blog minurne.blog4ever.com:

"Three years ago, faced with the terrible threats hovering over France, we created" Minurne ", a free space for information and debates aimed at combating misinformation and intoxication practiced by the media at the orders of the public well-thinking and politically correct."

This is also the case on the Boulevard Voltaire website, which states: "Reading, listening to, drinking or eating traditional media can cause serious illnesses".

The practice and discourses of re-information thus make a diverted use of the prefix re-, which is rather a bearer of a necessity of rupture, in the sense of tabula rasa, even of a certain "authoritarian" tone where re-inform refers to imposing a belief, despite its unfounded status. In this case, the re- is far from conforming to its usual meanings: start again, redo, restore, renew, repeat. Paradoxically, the re-informing sites have a form of attachment to the words they seek to avoid (lexicon of the media and traditional journalists), which is the case, for example, of the site Polemia.com, which proposes to warn against a set of words and concepts such as among others: "misleading words, subliminal words, markers, taboo words and astonishing words, fetish words: ex. Democracy, amazing words: ex. Anyone who does not think rightly is considered to be a Euro-phobic, xenophobic, nationalist, populist, or even extreme right ". 
In our study, we did not deal with ideological content but with ways of designating the very act of re-informing. For this purpose, we refer to studies in History and Political Science (including Winock 1993 in History, Camus 1996 and 2008, Taguieff 2012 in Political Studies), but also to the Dictionary of the Far Right under the direction of Lecoeur (2007). Our description allowed us to situate the re-information in the discourse of the false information, but also to insist on the posture of the reader who adheres to these discourses, posing the truth and the cancellation of what pre-exists. Bronner rightly invites this reader confronted with such sites to remain vigilant and to try to mitigate the influence of this false information (BRONNER, 2013a). To this end, he emphasizes the role of the school in learning to think:

Education can not remove the misleading suggestion of our senses, but it can sharpen a reflex of mistrust. We will always feel the mental temptation to perceive the world in an egocentric way, but our education can help us to compete against it with a more methodical vision. (2013a, 310)

Thus, we have, through this study, the example of a deceptive use of the prefix re-. Contrary to what the re-information site Novepresse.info announces on its home page: "Novo means, in Latin, to renew or to redo again. Novopress aims to redo information in the face of the unique ideology ", the work of re-information is more focused on a counterinformation revealing the reasons of erasure and resetting than on a renewal. Thus, to understand this use of the prefix re-, reading the history of ideas of the extreme right (Winock et al.) can elucidate; it would rather be a "return to an initial state" effect, as in a Myth of Eternal Return (ELIADE, 1969), a return to what is presented in these sites as lost, that is to say the true values of France. 


\section{References}

AMIOT, Dany. "Re-, préfixe aspectuel", Cahiers Chronos No. 10, Amsterdam: Rodopi, p. 1-20, 2002.

BADOUARD, Romain. Le désenchantement de l'internet. Désinformation, rumeur et propagande, Editions FYP, coll. "Presence / Social Issues", 2017.

BLANC, Charlotte, "Réseaux traditionalistes catholiques et «réinformation» sur le web: mobilisations contre le « Mariage pour tous » et «pro-vie »", tic \& society [Online], Vol. 9, No. 1-2 | 1st semester 2015 - 2nd semester 2015, posted on 11 January 2016, accessed on 27 November 2017. URL: http://ticetsociete.revues.org/1919

BRONNER, Gérald. La démocratie des crédules, Paris: PUF, 2013 a.

$\overline{2013 b .}$

Croyances et imaginaires contemporains, Paris: Editions Manucius,

BRONNER, Gérald and GEHIN, Étienne. L'inquiétant principe de précaution, Paris: PUF, 2010.

CAMUS, Jean-Yves. L'extrême droite aujourd'hui, Toulouse: The essentials Milan, 1996.

CARDON, Dominique and Granjon, Fabien. Médiactivistes, Paris: Sciences Po Presses, 2010.

CHOMSKY, Noam and HERMAN Edward. La fabrication du consentement. De la propagande médiatique en démocratie. Paris: Agone publisher, coll. "Backfires", 2008.

ELIADE, Mircea Mythe de l'éternel retour. Archétypes et répétition, Paris: Gallimard, 1969.

GLEVAREC, Hervé; MACÉ, Eric; MAIGRET, Eric Cultural Studies Anthologie, Paris: Armand Colin, 2008.

JALENQUES, Pierre "Étude sémantique du préfixe re- en français contemporain : à propos de plusieurs débats actuels en morphologie dérivationnelle", in French language Vol. $144 \mathrm{~N}^{\circ} 1$ The lexicon, between identity and variation, p. 74-90, 2002

JALENQUES, Pierre Contribution à l'étude du préfixe RE en français contemporain : pour une analyse compositionnelle du verbe regarder, University of Paris 7: doctoral thesis, 2000.

JAMMET, Thomas And GUIDI, Diletta "Observer Les Observateurs. Du pluralisme médiatique au populisme anti-islam, analyse d'un site de "réinformation » suisse et de ses connexions", Networks 2017/2 (n $\left.{ }^{\circ} 202-203\right)$, p. 241-271, 2017.

LECOEUR, Erwan (ed.), Dictionnaire de l'extrême droite, Paris, Larousse, 2007.

MASCHRIN, Laurent. Analyse morphosémantique de l'aspectuo-temporalité en français. Le cas du préfixe re-. University of Nancy II: PhD thesis, 2007. 
MERCKLÉ, Pierre Sociologie des réseaux sociaux, Paris: Discovery, 2004a.

MILZA, Pierre Fascisme français Passé et présent, Paris: Champs Flammarion, 1987.

PICOCHE, Jacqueline Précis de lexicologie française, Paris: Vigor Editions, 1992.

SCHMELCK, Clara "Plongée en fachosphère", Medium 2017/3 (N 52-53), p. 199-212, 2017.

TAGUIEF, Pierre-André Le nouveau national-populisme, Paris: CNRS Éditions, 2012.

WINOCK, Michel (ed.) Histoire de l'extrême droite en France, Paris, Éditions du seuil, 1993. 